\title{
Fear, Deposit Insurance Schemes, and Deposit Reallocation in the German Banking System
}

Fecht, Falko ${ }^{a}$; Thum, Stefan ${ }^{b}$ and Weber, Patrick ${ }^{c}$

${ }^{\mathrm{a}}$ Frankfurt School of Finance and Management, Germany, ${ }^{\mathrm{b}}$ Deutsche Bundesbank, Division Securities and Money Market Statistics, Germany, ${ }^{\mathrm{c} D e u t s c h e}$ Bundesbank, Division Securities and Money Market Statistics, Germany.

\begin{abstract}
Recent regulatory initiatives such as the European Deposit Insurance Scheme propose a change in the coverage and backing of deposit insurances. An assessment of these proposals requires a thorough understanding of what drives depositors' withdrawal decisions. We show that Google searches for 'deposit insurance' and related strings reflect depositors' fears and help to predict deposit shifts in the German banking sector from private banks to fully guaranteed public banks. After the introduction of blanket state guarantees for all deposits in the German banking system this fear driven reallocation of deposits stopped. Our findings highlight that a heterogeneous insurance of deposits can lead to a sudden, fear induced reallocation of deposits endangering the stability of the banking sector even in absence of redenomination risks.
\end{abstract}

Keywords: Depositor expectations, Google, Deposit insurance, Competition for depositors, Bank runs. 